$\begin{array}{ll}\text { Abstracta Iranica } & \begin{array}{l}\text { Abstracta Iranica } \\ \text { Revue bibliographique pour le domaine irano-aryen }\end{array} \\ & \text { Volume } 22 \mid \mathbf{2 0 0 1} \\ & \text { Comptes rendus des publications de } 1999\end{array}$

\title{
Kitābuna daryābuna. Peshawar, 1997, 544 p. [Livres océans]
}

\section{Nadjib Manalaï}

\section{OpenEdition}

1 Journals

\section{Édition électronique}

URL : http://journals.openedition.org/abstractairanica/37189

DOI : 10.4000/abstractairanica.37189

ISSN : 1961-960X

Éditeur :

CNRS (UMR 7528 Mondes iraniens et indiens), Éditions de l'IFRI

\section{Édition imprimée}

Date de publication : 15 mai 2001

ISSN : 0240-8910

\section{Référence électronique}

Nadjib Manalaï, « Kitābuna daryābuna. Peshawar, 1997, 544 p. [Livres océans] », Abstracta Iranica [En ligne], Volume 22 | 2001, document 578, mis en ligne le 17 février 2010, consulté le 13 octobre 2020. URL : http://journals.openedition.org/abstractairanica/37189; DOI : https://doi.org/10.4000/ abstractairanica.37189

Ce document a été généré automatiquement le 13 octobre 2020.

Tous droits réservés 


\title{
Kitābuna daryābuna. Peshawar, 1997, 544 p. [Livres océans]
}

\author{
Nadjib Manalaï
}

1 Habibollāh Rafi' a écrit de nombreuses préfaces, commentaires et critiques pour des œuvres contemporaines et pour des éditions critiques des œuvres classiques. Il a rassemblé dans ce recueil une cinquantaine de tels écrits. Pour les œuvres classiques et semi-classiques l'A. fait, avec une grande érudition, le point des connaissances actuelles sur le sujet et sur l'auteur.

2 Quant aux œuvres contemporaines (14 essais, 6 récits et 13 recueils de poèmes) l'A. donne une appréciation plus personnelle.

3 Par la place que H. Rafi' occupe dans le paysage culturel afghan, l'ouvrage apparaît comme un document de qualité sur l'état de la littérature et de la recherche en sciences sociales dans les milieux afghans au cours des années de guerre.

\section{INDEX}

Thèmes : 11.2. Littérature pashto et dari (Afghanistan)

\section{AUTEURS}

NADJIB MANALAÏ

INALCO - Paris 